\title{
Distribution patterns of polychaete fauna in an Arctic fjord (Hornsund, Spitsbergen)
}

\author{
Monika Kędra • Krzysztof Pabis · Sławomira Gromisz • \\ Jan Marcin Węsławski
}

Received: 7 November 2012/Revised: 20 June 2013 / Accepted: 28 June 2013 / Published online: 3 August 2013

(C) The Author(s) 2013. This article is published with open access at Springerlink.com

\begin{abstract}
Polychaetes are one of the most important groups of benthic organisms in marine ecosystems. They dominate on the Arctic shelf and play an important role in ecosystem functioning. This study focuses on the polychaete biodiversity and their distribution patterns in Hornsund, an open glacial fjord, in western Spitsbergen and provides important baseline data for future studies of temporal fluctuations in benthic fauna. The main aim of this study was to assess how the polychaete abundance, biomass, diversity, community structure, and function vary along the Hornsund fjord's axis, in relation to the environmental factors. Eighty-eight polychaete taxa were identified; an average density was 457 ind. $\mathrm{m}^{-2} \pm$ 237.5 SD. Three assemblages were distinguished (INNER, $M I D D L E$, and $O U T E R$ ) along the fjord axis, reflecting the intensity of glacial disturbance. A clear division between the highly disturbed inner part of the fjord (Brepollen) and the less impacted middle and outer parts was observed. Continuous gradients in abundance, biomass, and diversity were found with all those values diminishing toward the inner region of the fjord. The polychaete assemblages' indices were significantly correlated with bottom temperature, sediment characteristics (grain size), and distance to
\end{abstract}

M. Kędra $(\bowtie) \cdot$ J. M. Węsławski

Institute of Oceanology Polish Academy of Sciences (IOPAN), Powstańców Warszawy 55, 81-712 Sopot, Poland

e-mail: kedra@iopan.gda.pl

K. Pabis

Laboratory of Polar Biology and Oceanobiology, University of Łódź, ul. Banacha 12/16, 90-237 Łódź, Poland

S. Gromisz

National Marine Fisheries Research Institute, ul. Kołłątaja 1, 81-332 Gdynia, Poland the glacier (longitude). No significant correlations were found with depth or total organic carbon content. Carnivore and motile surface deposit feeding polychaete species dominated in the areas close to the glaciers, while the OUTER community was dominated by carnivores and surface sessile and discretely motile species, and had more complex trophic structure, with multiple species representing different functional groups including carnivores, sessile, discretely motile, and motile surface deposit feeders and motile burrowers.

Keywords Polychaeta $\cdot$ Svalbard · Fjords · Diversity Patterns of distribution

\section{Introduction}

Polar fjord benthic ecosystems are strongly affected by natural disturbance processes associated with tidewater glacier activity (Włodarska-Kowalczuk and Pearson 2004; Pabis and Siciński 2010; Ronowicz et al. 2011). The influence of meltwater and the suspended sediment inflow are among the most important physical forces shaping the polar marine communities of tidewater glacial fjords. Arctic biota is currently affected by large-scale climate warming (Steele et al. 2008; Turner and Overland 2009; Walsh 2009; Polyakov et al. 2010) that can substantially increase the glacial activity causing a higher rate of suspended sediment inflow (Syvitski and Andrews 1994). The influence of those processes is expected to result in increasing homogenization of benthic habitats (Kędra et al. 2010a; Węsławski et al. 2011) and changes in the Arctic food web (Grebmeier et al. 2006; Post et al. 2009; Feder et al. 2011; Grebmeier 2012).

Environmental gradients, such as sediment disturbance, organic content change, and intensified sediment 
deposition at the frontal zone of glaciers, are present in many glacial fjords. Benthic diversity and biomass can change significantly from the outer to the inner parts of Arctic and Subarctic fjords (Kendall and Aschan 1993; Holte and Oug 1996; Włodarska-Kowalczuk et al. 2005; Blanchard et al. 2010). The chronic disturbance associated with glacial activity is especially visible in the shallow areas located close to the glacial terminus (WłodarskaKowalczuk et al. 1998; Włodarska-Kowalczuk and Pearson 2004; Siciński et al. 2012); however, this influence can be very strong to as deep as $100 \mathrm{~m}$ (Siciński 2004). Thus, it is important to show the effects of glacial disturbance on benthic fauna in the deeper parts of fjords.

Polychaetes are one of the most important groups of benthic organisms in marine ecosystems (Knox 1977). They are numerical dominants in most Arctic soft-sediment shelf systems (Kendall et al. 2003). Further, they are known to be good indicators of species richness and benthic community patterns as well as ecosystem condition (Pearson and Rosenberg 1978; Pocklington and Wells 1992; Olsgard and Somerfield 2000; Olsgard et al. 2003; Giangrande et al. 2005; Włodarska-Kowalczuk and Kędra 2007). Polychaetes play considerable and diverse roles in ecosystem functioning, not only because of their dominance, but also because of their diverse feeding modes and reproductive strategies (Fauchald and Jumars 1979; Snelgrove et al. 1997). Polychaetes, as a result of their burrowing and feeding activities, enhance sedimentary processes by recycling and reworking of sediments, bioturbation, redistribution and burial of organic matter, and remineralization processes (Hutchings 1998). Sessile suspension feeders play an important role in energy transfer from the pelagic to the benthic zone (Fauchald and Jumars 1979; Rouse and Pleijel 2001).

This study addressed the polychaete biodiversity and distribution patterns in the fjord and was conducted within the framework of an extensive survey that focused on the Hornsund benthic ecosystem, which took place as a part of Census of Marine Life-Arctic Ocean Biodiversity project. Hornsund, an open glacial fjord in western Spitsbergen, a representative of typical Arctic marine ecosystems, was selected as one of the "All Taxa Biodiversity Inventory" (ATBI) sites during the EU 5th Framework Concerted Action BIOMARE (2000-2002), later continued by Marine Biodiversity and Ecosystem Functioning EU Network of Excellence MarBEF (Warwick et al. 2003). Moreover, due to its location in the zone of increasing air temperature and increased transport of Atlantic-derived waters (the major heat distributors) on the West Spitsbergen Shelf (Walczowski and Piechura 2006, 2007; Piechura and Walczowski 2009), Hornsund was chosen as an important site for monitoring the effects of climate change (Warwick et al. 2003). Prior benthic investigations in Hornsund focused on other macrozoobenthic groups: hydrozoans
(Ronowicz et al. 2008), amphipods (Jażdżewski et al. 1995; Legeżyńska et al. 2000), and sipunculans (Kędra and Murina 2007; Kędra and Włodarska-Kowalczuk 2008). Ronowicz (2005) investigated macrofaunal distribution on gravel beaches, and Włodarska-Kowalczuk et al. (2009) described macrofaunal assemblages associated with macroalgae in the Arctic kelp forest. The literature on the ecology of polychaetes in the Svalbard fjords, and Hornsund in particular, is scarce. The only attempt to describe Hornsund subtidal benthic fauna was made over 30 years ago by Görlich et al. (1987), but the main purpose of their study was related to the effect of settling sediment on benthic biomass in the fjord. An early list of polychaetes in the shallow depths of the Hornsund fjord was provided by Gromisz (1992). Recently, an updated species list is included in Kędra et al. (2010b).

The main aim of this study was to assess how polychaete abundance, biomass, diversity, community structure, and function vary along the Hornsund fjord axis in relation to the environmental factors. The paper provides important baseline data for future studies of temporal fluctuations in benthic fauna and supplements Gromisz (1992), which focused only on the polychaete fauna of the shallow sublittoral.

\section{Materials and methods}

\section{Study area}

Hornsund is an open, medium-size Arctic glacial fjord (30 km length, 12-15 km wide; average depth $90 \mathrm{~m}$, max. $260 \mathrm{~m})$ located on the west coast of Spitsbergen $\left(76-77^{\circ} \mathrm{N}\right.$; Fig. 1). The fjord hydrology is influenced by the cold Sørkapp Current carrying Arctic waters from the eastern part of Svalbard. The fjord opening is also exposed to coastal, warmer, and more saline Atlantic waters carried by West Spitsbergen Current. The inner shallow fjord basin, Brepollen, is filled with winter cooled water of temperature below $0{ }^{\circ} \mathrm{C}$ through all the year (Swerpel 1985; Węsławski et al. 1991; Węsławski et al. 1995). Brepollen (the glacial bay) is partially isolated from the remaining part of the fjord by the Treskelen Peninsula and is almost entirely formed by the cliffs of five tidal glaciers. Up to $12 \%$ of the water mass in the inner basin is derived from the freshwater runoff of the glacier (Węsławski et al. 1991). Topographical isolation, presence of glaciers and related high sedimentation, and input of freshwater from glacier channels and rivers cause visible water column stratification. During the summer, impact of glacier meltwater results in high amounts of inorganic suspension (Hop et al. 2002; Svendsen et al. 2002), produces steep horizontal gradients of water turbidity and sedimentation along the fjord axis, and reduces thickness of the euphotic layer (Urbański et al. 
1980; Piwosz et al. 2009). Persistence of ice cover, high water turbidity, and high sediment flux to the bottom in the inner basin reduces primary production and results in a reduced amount of organic matter in the sediment of the region compared to the outer fjord (Görlich et al. 1987; Eilertsen et al. 1989; Piwosz et al. 2009). The sediment accumulation rate in Brepollen can reach $35 \mathrm{~cm} \mathrm{year}^{-1}$, while in the outer parts of Hornsund it is as low as $0.1 \mathrm{~cm} \mathrm{year}^{-1}$ (Görlich et al. 1987). The fjord floor is covered mostly with mud (Grzelak and Kotwicki 2012). Total organic carbon (TOC) reaches values between 1.75 and $1.99 \%$ in the inner basin and between 1.37 and $1.84 \%$ ( $0.80 \%$ close to Hansbreen glacier) in the outer part of the fjord (Schettler and Szczucinski, unpublished data; Szczucinski et al. 2006).

\section{Sampling}

Material was primarily collected during the cruises of RV Oceania in July in 2007, when 22 stations, across the whole fjord, were sampled. Additional 7 stations were sampled in 2005 and 2006. Altogether 29 stations located throughout the fjord at depths varying from 100 to $250 \mathrm{~m}$ were sampled with van Veen grab, resulting in altogether in 39 samples $\left(0.1 \mathrm{~m}^{2}\right.$ sample area; single grab, with an exception of 2006 and two stations sampled in 2007, when three replications per station were taken; Fig. 1). Samples were sieved onboard through $0.5-\mathrm{mm}$ mesh and fixed in buffered $4 \%$ formaldehyde solution. Macrofauna was sorted, polychaetes were picked up, identified to the lowest possible taxonomic level, counted, and weighted (wet formalin weight). The taxonomic identification of polychaetes was based on Holthe (1986), Hartmann-Schröder (1996), and Jirkov (2001). Feeding guilds are after Fauchald and Jumars (1979).
Data analysis

Species-accumulation curves with $95 \%$ confidence intervals were computed using the formulae of Colwell (2009). Non-metric multidimensional scaling (nMDS) of BrayCurtis similarities, computed after square root transformation of species level abundance data, was conducted. One-way ANOSIM permutation tests of the Bray-Curtis similarity data were performed (Clarke and Warwick 2001) in order to test for differences in community composition in different fjord's areas. Indices of species richness $(S-$ number of species in sample) and species diversity (Hurlbert rarefaction index- $\operatorname{ES}[n]$, where $n=50$ ) were measured for each sample (Magurran 2004). Mean values with $95 \%$ confidence limits were calculated for density and biomass values, and diversity indices in each of distinguished assemblages and differences were tested with the use of the nonparametric Kruskal-Wallis test and post hoc multiple comparisons (Dunn's test). Frequency $(F)$ as a percentage of total occurrences was calculated for each taxon. To assess the relationship between environmental variables and specific faunal community characteristics, Spearman' correlation analysis was used, and for community characteristics relationship with environment, the BIOENV was applied. The data analyses were performed using the PRIMER package version 6 (Clarke and Warwick 2001), the Statsoft software STATISTICA version 6, and EstimateS (Colwell 2009).

\section{Results}

Eighty-eight taxa belonging to 28 families were identified in the investigated area. Species-accumulation curves were close to asymptotic in the Sobs and Chao2 values for the
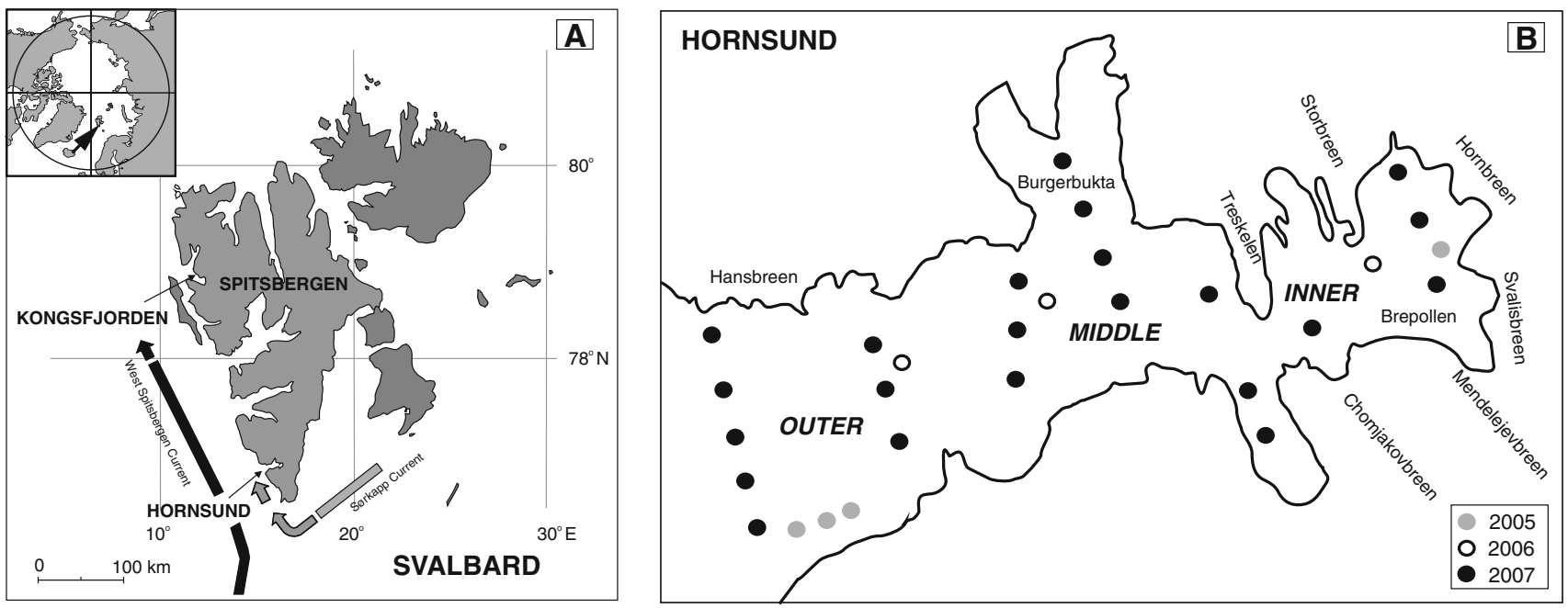

Fig. 1 a Location of Hornsund fjord; b sampling location in Hornsund: samples collected in 2005 (gray), 2006 (white), and 2007 (black) 
estimated number of species. Chao2 gave an estimate of 99 species. The collected number of species was close to the 0.95 confidence interval of estimated number of species (with $95 \%$ confidence intervals from 88 to 133).

Three assemblages were distinguished in the MDS analysis (Fig. 2), with significant differences (0.75; $p<0.05)$ between each assemblage indicated by the ANOSIM test. The groups represent three different areas along the fjord axis (Fig. 1), with an exception of station taken close to Treskelen which, even though taken in Brepollen clustered with MIDDLE assemblage (Fig. 2). Species richness, diversity, biomass, and density changed gradually along the axis of the fjord from the highest in the outer part to the lowest in Brepollen located in the innermost part of Hornsund (Fig. 3). There were significant differences between OUTER and MIDDLE assemblages for species richness, diversity, and biomass; between MIDDLE and INNER for density and biomass; and between OUTER and INNER for all indices (Dunn's test, $p<0.05$ ).

The OUTER assemblage, at the outer part of the fjord, was the most diverse with 83 taxa found. On average, 586.6 ind. $\mathrm{m}^{-2} \pm 283.0$ and $29.2 \pm 6.3$ polychaete species were found. The biomass ranged from 8.1 to $17.8 \mathrm{~g}$ $1 \mathrm{~m}^{-2}$ with an average of $10.5 \pm 5.0$ (Fig. 3). This assemblage was dominated by cirratulids (Aphelochaeta spp./Chaetozone spp.; 143.4 ind. $0.1 \mathrm{~m}^{-2} \pm 143.1$,
$F=100$ ) followed by Lumbrineris spp. (91.0 ind. $0.1 \mathrm{~m}^{-2} \pm 38.4, \quad F=100 \%$ ), and sessile subsurface deposit feeder Maldane sarsi $\left(71.1\right.$ ind. $0.1 \mathrm{~m}^{-2} \pm 43.3$, $F=93 \%$ ). Cirratulus cf. caudatus occurred only in the OUTER association (23.2 ind. $0.1 \mathrm{~m}^{-2} \pm 24.3$; Table 1). A wide range of feeding guilds was present at the fjord mouth, including motile carnivores (e.g., Lumbrineris spp.), sessile and discretely motile surface deposit feeders (e.g., Ampharete finmarchica and Apistobranchus tullbergi), and subsurface deposit feeders (e.g., Leitoscoloplos mammosus) (Table 2). Carnivores and surface sessile and discretely motile species were dominant functional groups.

Forty-nine taxa were found in the central part of the fjord (MIDDLE assemblage). On average, 452.6 ind. $0.1 \mathrm{~m}^{-2} \pm 181.9$ and $18.2 \pm 4.7$ taxa were found and 1.0

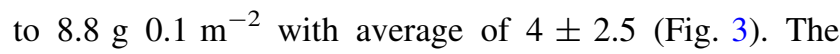
most abundant taxa were similar to those from the previous group but with clearly lower density of $M$. sarsi (22.8 ind. $0.1 \mathrm{~m}^{-2} \pm 32.8, F=96 \%$ ) and higher cirratulids' densities (232.9 ind. $0.1 \mathrm{~m}^{-2} \pm 127.1, F=100 \%$; Table 1). Some taxa that were important part of the outer community, e.g., A. tullbergi, were almost missing from the middle part of the fjord (Table 1). This assemblage was dominated by surface and subsurface deposit feeders in the areas close to the shore. However, in the central part, and more toward the mouth of the fjord, more sessile surface

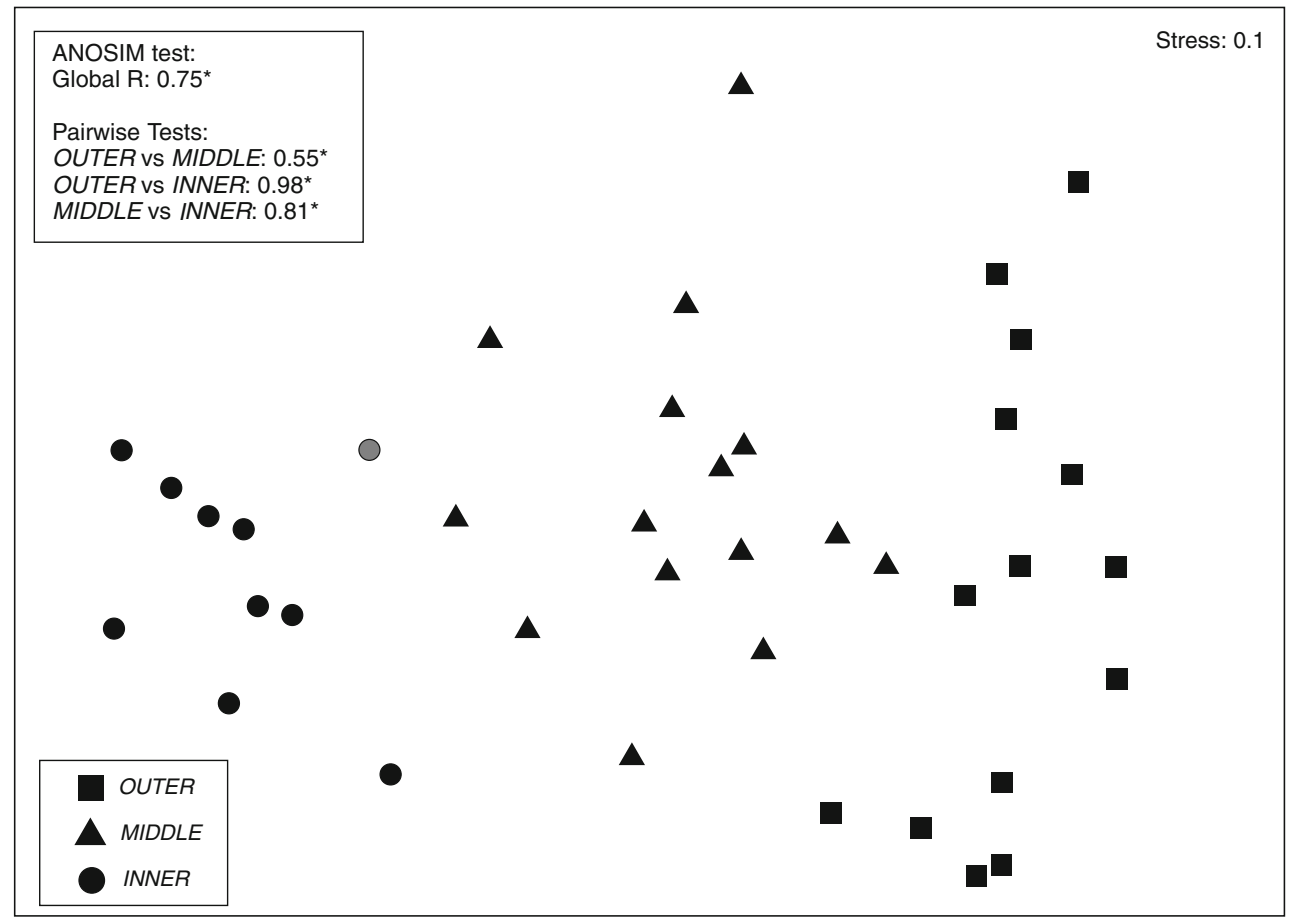

Fig. 2 Non-metric multidimensional scaling (nMDS) of Bray-Curtis similarities of square-root-transformed data of polychaete species densities in Hornsund. The results of ANOSIM tests for differences between Hornsund areas are presented on the plot. Square OUTER, triangle MIDDLE, circle INNER (in gray station located in Brepollen that clustered with MIDDLE assemblage). Significant test results are marked with asterisk 
Fig. 3 Mean with 0.95 confidence intervals for: $D$ density (number of individuals $0.1 \mathrm{~m}^{-2}$ ), $B$ biomass (wet weight $\mathrm{g} 0.1 \mathrm{~m}^{-2}$ ), $S$ species richness (number of species), and ES[50]—Hurlbert rarefaction index for each station. Kruskal-Wallis test results are given with significant results marked with asterisk
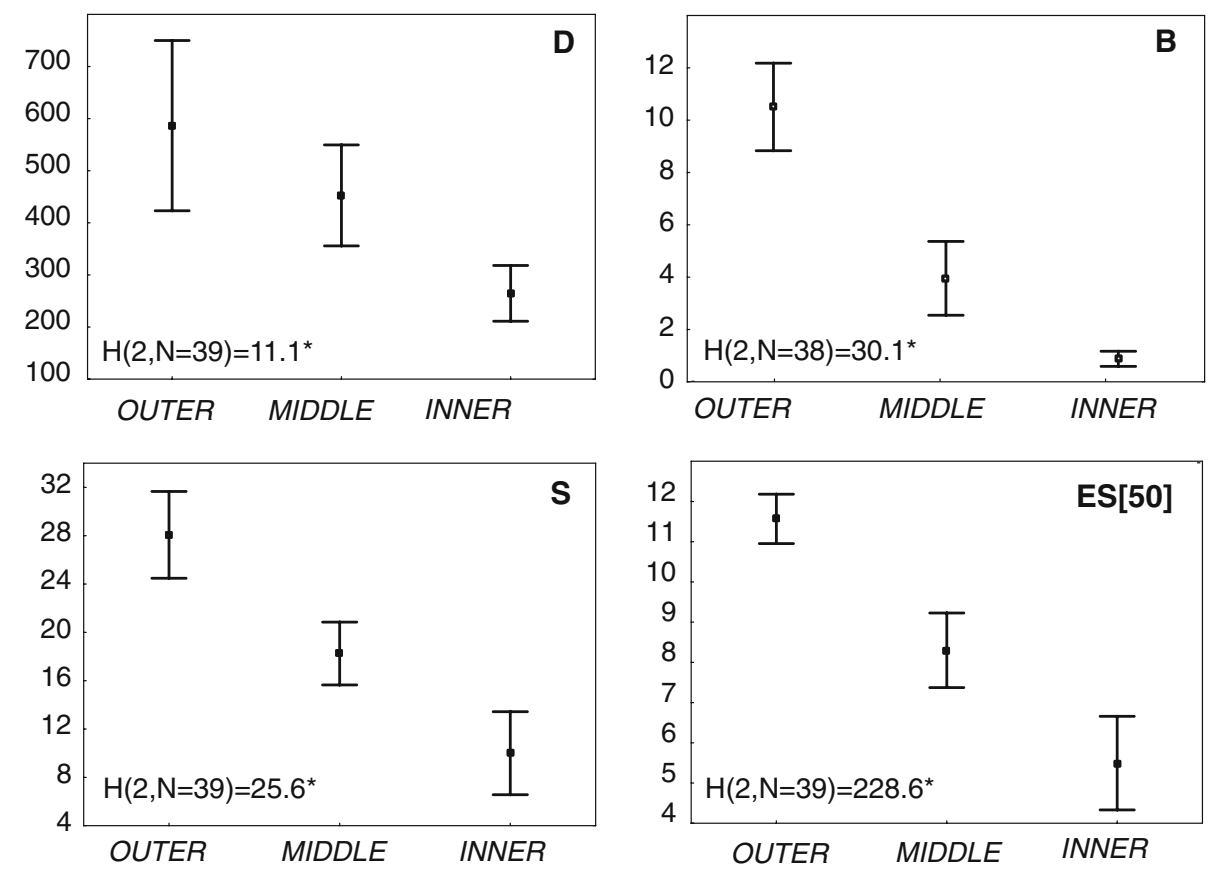

deposit-feeding polychaetes (e.g., Lanassa nordenskioldi) were present and more carnivores were found (e.g., Lumbrineris spp., Eteone longa, E. flava, and Pholoe assimilis; Table 2).

Species richness, diversity, evenness, and density were the lowest in Brepollen (INNER assemblage), and only 28 taxa were found there (Fig. 3). On average, 264.7 ind. $0.1 \mathrm{~m}^{-2} \pm 69.6$ and $10.0 \pm 4.5$ taxa were found. Biomass ranged from 0.5 to $1.6 \mathrm{~g} 0.1 \mathrm{~m}^{-2}$ with average of $0.9 \pm 0.4$ (Fig. 3). This part of the fjord was strongly dominated by cirratulids (Aphelochaeta spp./Chaetozone spp.; 190.0 ind. $0.1 \mathrm{~m}^{-2} \pm 49.8, F=100 \%$ ), terebelid Polycirrus arcticus (11.1 ind. $0.1 \mathrm{~m} \pm 9.9, F=100 \%$ ), and small sabellids: Chone spp. (2.1 ind. $0.1 \mathrm{~m}^{-2} \pm 4.3$, $F=44 \%$ ) and Euchone spp. (6.6 ind. $0.1 \mathrm{~m}^{-2} \pm 7$, $F=67 \%$; Table 1). L. mammosus and A. tullbergi were not present in this part of the fjord, while Prionospio cirrifera and Aglaophamus malmgreni occurred only here. Brepollen was dominated by motile carnivores (e.g., A. malmgreni and Bylgides elegans) and surface deposit feeders (e.g., Polydora sp.) (Table 2).

Overall, polychaete biomass, diversity, and species richness showed the best correlation with bottom temperature, sediment type, and distance from the glacier (Table 3). Polychaete community structure and environmental factors were significantly correlated (BIOENV, $\rho=0.73, p=0.01$ ), and the combination of habitat variables identified by BIOENV as best explaining variation in community structure included temperature and distance to the glacier (longitude). Next best combination included temperature, longitude, and very fine sand ( $\rho=0.69)$.

\section{Discussion}

Eighty-eight soft-bottom polychaete taxa were identified during this study. Previous shallow study (depths of 0.5-80 m) from 1979 to 1982 conducted in Hornsund listed 48 species (Gromisz 1992). Even though the list provided by Gromisz (1992) is considerably smaller than the one obtained in 2005-2007, it still contains species not found in the present study, mainly due to the differences in sampling depths. For example, Pygospio elegans and Nereis pelagica, abundant species in Gromisz's study, are shallow, sublittoral species (Hartmann-Schröder 1996). However, Gromisz (1992) listed species typical of greater depths (Hartmann-Schröder 1996) like Nothria conchylega, Nephtys hombergii, and Phyllodoce citrina that were not present in our more extensive study. Włodarska-Kowalczuk et al. (2009) found 52 polychaete species on kelp fronds and holdfasts in Hornsund but no species list was provided. We can assume that the kelp-associated fauna is different from the soft-bottom fauna investigated in this study, as it was observed before in Hornsund (Gromisz 1992) and in Kongsfjorden (Lippert et al. 2001). Also, results obtained from asymptotic curves suggest that the polychaete species of Hornsund is not yet complete.

Hornsund is characterized by higher average polychaete density compared to other Svalbard fjords (457 ind. $\mathrm{m}^{-2}$ (this study) versus 310 ind. $\mathrm{m}^{-2}$ in Kongsfjorden (Włodarska-Kowalczuk and Pearson 2004; Kędra et al. 2010a), 133 ind. $\mathrm{m}^{-2}$ in van Mijenfjord (Renaud et al. 2007). A similar pattern of high meiofaunal density in Hornsund was found by Grzelak and Kotwicki (2012). Mean 


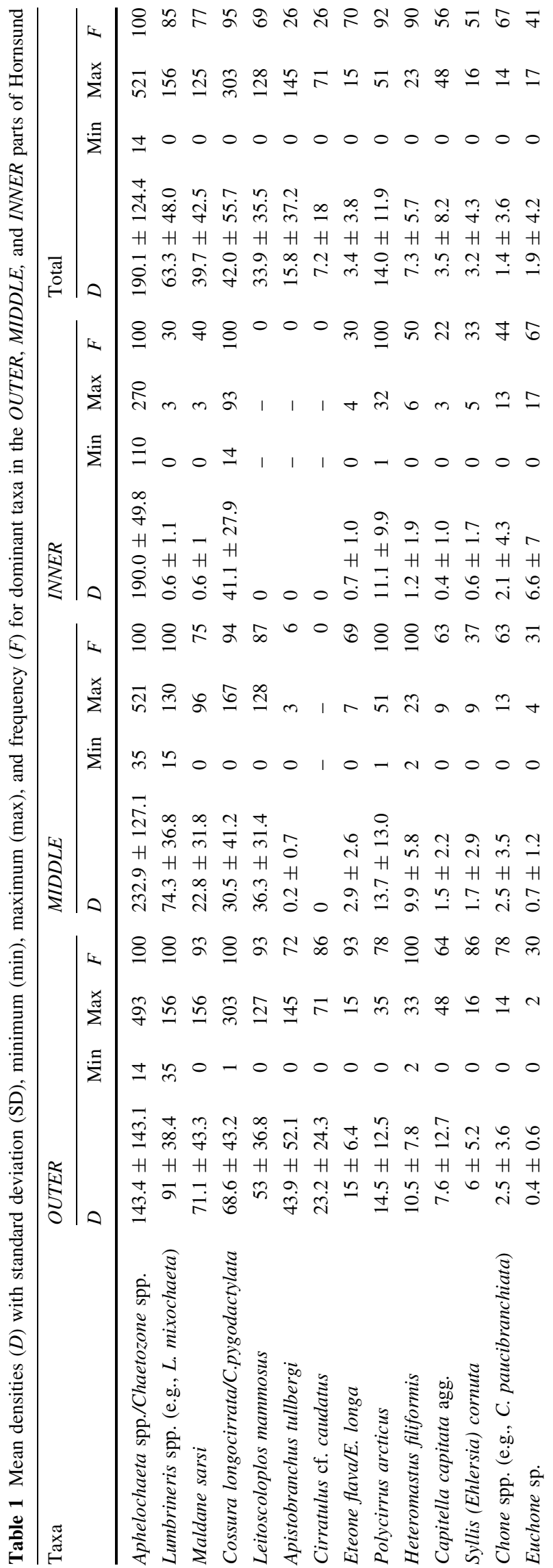

Table 2 Functional group in different polychaete assemblages in Hornsund

\begin{tabular}{lllr}
\hline Functional group & INNER & \multicolumn{1}{l}{ MIDDLE } & \multicolumn{1}{l}{ OUTER } \\
\hline C-m & $9(2.9 \pm 1.3)$ & $13(5.1 \pm 1.7)$ & $20(6.6 \pm 1.7)$ \\
C-d & 0 & 0 & $1(0.1 \pm 0.2)$ \\
Sf-s & $1(0.1 \pm 0.3)$ & $7(1.2 \pm 1.4)$ & $13(4.1 \pm 2.1)$ \\
Sf-d & $5(1.4 \pm 1.0)$ & $8(2.9 \pm 1.4)$ & $12(5.1 \pm 1.4)$ \\
Sf-m & $5(2.1 \pm 0.9)$ & $6(2.7 \pm 1.1)$ & $8(4.3 \pm 0.8)$ \\
Sub-s & $1(0.4 \pm 0.5)$ & $5(0.9 \pm 0.7)$ & $3(1.2 \pm 0.4)$ \\
Sub-m & $3(1.8 \pm 0.6)$ & $8(4.1 \pm 1.2)$ & $8(4.6 \pm 1.4)$ \\
Sus-s & $3(1.2 \pm 1.1)$ & $2(1.2 \pm 0.7)$ & $6(1.8 \pm 1.1)$ \\
\hline
\end{tabular}

Number of species in each assemblage is given. In brackets, average number of species and SD per sample is given

$c$ Carnivore, $s f$ surface, sub subsurface, sus suspension, $s$ sessile, $m$ motile, $d$ discretely motile

concentration of TOC in Hornsund sediments was $1.58 \%$, which is higher than in other Svalbard locations (Schettler and Szczucinski, unpublished data; Szczucinski et al. 2006), e.g., mean TOC in Kongsfjorden sediments was $0.85 \%$ (Włodarska-Kowalczuk and Pearson 2004). This can be explained by higher (4 times and more) primary productivity of the water column in Hornsund than in Kongsfjorden (Piwosz et al. 2009), and low temperature near the bottom supporting faunal abundance and biomass growth. Since zooplankton abundance in Hornsund is relatively low (Piwosz et al. 2009), much of the ungrazed primary production settles to the sea bottom. The considerable flux of primary production and TOC to the seafloor controls the production of the benthic fauna (e.g., Ambrose and Renaud 1995; Danovaro et al. 1999) and may result in high densities of polychaetes in Hornsund.

A clear division between the highly impacted glacial activity region in Brepollen and the reduced glacial effect in the middle and outer part of the fjord was observed. A continuos gradient in polychaete abundance, biomass, and diversity occurred between the inner and outer part of the fjord. This distribution pattern showed tendencies similar to those observed for other Svalbard fjords (Görlich et al. 1987; Holte et al. 1996; Włodarska-Kowalczuk and Pearson 2004) and shallow Hornsund bays (Gromisz 1992). Similar patterns of physically controlled faunal composition were observed for the benthic fauna in the Brepollen region (Włodarska-Kowalczuk and Węsławski 2008) and in Kongfjorden (Włodarska-Kowalczuk and Pearson 2004). Low faunal abundance and biomass in glacial bays were related to sediment processes that included a high sedimentation ratio, high sediment instability, and relatively low content of organic matter (Görlich et al. 1987). Our study indicated that low polychaete biomass, density, and diversity in Brepollen are associated mostly with glacier-derived influence, finer sediments, and lower temperature. The inner fjord basin is 
Table 3 Spearman's correlation coefficients relating polychaete biomass, abundance, species richness, and diversity (ES[50]) to environmental variables

* Significant values

\begin{tabular}{lcccc}
\hline Environmental variable & Biomass & Abundance & Species richness & $\begin{array}{l}\text { Species diversity } \\
\text { ES[50] }\end{array}$ \\
\hline Depth & $0.34^{*}$ & -0.15 & 0.11 & 0.10 \\
Bottom temperature & $0.89^{*}$ & $0.42^{*}$ & $0.82^{*}$ & $0.87^{*}$ \\
Grain size $(\%<63 \mu \mathrm{m})$ & $-0.61^{*}$ & $-0.38^{*}$ & $-0.49^{*}$ & $-0.54^{*}$ \\
Grain size $(\%$ sand) & $0.61^{*}$ & $0.38^{*}$ & $0.49^{*}$ & $0.54^{*}$ \\
TOC (total organic carbon) & -0.15 & -0.22 & -0.10 & -0.20 \\
Distance from the glacier & $-0.9^{*}$ & $-0.56^{*}$ & $-0.85^{*}$ & $-0.85^{*}$ \\
$\quad$ (longitude) & & & & \\
\hline
\end{tabular}

community in the Kongsfjorden glacial bay while in this study, it was almost absent in Brepollen. It is likely that low density and biomass of both macro- (this study) and meiofauna (Grzelak and Kotwicki 2012) in the inner parts of Brepollen are not enough to support carnivore species, thereby affecting trophic relations there.

The fjord opening and the central region are characterized by higher faunal density and diversity than Brepollen. Here, the composition of benthic species is more likely controlled by biological interactions in the community rather than the physical stresses that occur in the inner glacially disturbed region of Hornsund (Włodarska-Kowalczuk and Węsławski 2008). High habitat heterogeneity, typical for Hornsund, (Warwick et al. 2003) also promotes higher species diversity. Higher species richness may additionally result from Atlantic and boreal and Arctic larvae transported by the Sørkapp and West Spitsbergen currents into Hornsund. Transport of Arctic species with water currents was observed in Hornsund for the phytoplankton communities (Piwosz et al. 2009). Sediment type is another important factor structuring benthic assemblages. In Hornsund, higher species richness and density, and more diverse trophic structure occurred where higher sand content was present, at the fjord opening. No significant correlations between polychaete community characteristics and TOC were found in Hornsund. In contrast to Kongsfjorden, where the level of TOC is constantly increasing toward the fjord mouth (Włodarska-Kowalczuk and Pearson 2004), Hornsund levels of TOC do not show a steep gradient (Schettler and Szczucinski, unpublished data; Szczucinski et al. 2006). High primary production in the outer part of Hornsund (Piwosz et al. 2009) resulting in greater food abundance reaching the bottom supports the diversity and density of higher trophic levels among infauna there. The increased density of higher trophic level taxa outside glacial bays indicates that more complex infaunal species interactions are important in structuring communities there (Ambrose 1984; Ambrose 1991).

The MIDDLE assemblage, though more abundant and with higher biomass than the INNER one, has a reduced density, diversity, and biomass compared to the OUTER region. Although the MIDDLE assemblage is less affected by 
glacial activity than fauna in Brepollen, it is still influenced by glaciers from the north in Burgerbukta and Chomjakovbreen in the southeastern region of the fjord and reduced diversity and productivity is observed there. A reduction in biomass and diversity was also noted next to the Hansbreen glacier in the outer part of the fjord. The capitellid Heteromastus filiformis, an opportunistic motile subsurface deposit feeder, was common in the central region of the fjord, rare in the outer part of the fjord, and absent in Brepollen. It was reported as a dominant in habitats disturbed by strong organic pollution (Pearson and Rosenberg 1978), as well as areas impacted by mine waste (Olsgard and Hasle 1993), but it does not tolerate mechanical disturbance of sediment (Beukema 1995). This probably explains its absence in Brepollen where there are sediment slides, gravity flows, and ice-berg scouring while in the outer part of the fjord, it might have been outcompeted by other species.

Polychaete communities in Hornsund are characterized by high species richness, density, and biomass, and different fjord area- and environment-related characteristics. Recent studies have demonstrated that changes in diversity of macrofaunal communities are dependent on the habitat type and differ between specific Arctic regions (Węsławski et al. 2011). Knowledge on the species diversity and species distribution patterns is essential to fully understand ecosystem functioning and potential climate-induced changes. Our study can be treated as a baseline for future studies of temporal fluctuations, especially observed glaciers retreat and associated changes in sedimentation and adds to current understanding of Hornsund system functioning.

Acknowledgments We would like to express our deep thanks to the r/v Oceania crew and Dr Marek Zajączkowski for help in sample collections. Many thanks to Georg Schettler from GeoForschungsZentrum in Potsdam and Witold Szczuciński from Adam Mickiewicz University in Poznan for providing their unpublished data. This study is a part of Arctic Ocean Diversity Project-Census of Marine Lifeand was completed thanks to financial support from the Polish Ministry of Science and Higher Education (540/N-AODP/2009/0). Krzysztof Pabis was partially financed from the University of Łódź internal funds. We would like to thank H. Feder, P.E. Renaud, and L.M. Clough for their constructive comments that greatly improved the quality of this manuscript.

Open Access This article is distributed under the terms of the Creative Commons Attribution License which permits any use, distribution, and reproduction in any medium, provided the original author(s) and the source are credited.

\section{References}

Ambrose WG Jr (1984) Influence of predatory polychaetes and epibenthic predators on the structure of a soft-bottom community in a Maine estuary. J Exp Mar Biol Ecol 81:115-145

Ambrose WG Jr (1991) Are infaunal predators important in structuring marine soft-bottom communities? Am Zool 31:849-860
Ambrose WG, Renaud PE (1995) Benthic response to water column productivity patterns: evidence for benthic-pelagic coupling in the Northeast Water Polynya. J Geophys Res 100:4411-4421

Beukema JJ (1995) Long-term effects of mechanical harvesting of lugworms Arenicola marina on the zoobenthic community of a tidal flat in the Wadden Sea. Neth J Sea Res 33:219-227

Blanchard AL, Feder HM, Hoberg MK (2010) Temporal variability of benthic communities in an Alaskan glacial fjord, 1971-2007. Mar Environ Res 69:95-107

Clarke KR, Warwick RM (2001) Change in marine communities: an approach to statistical analysis and interpretation, 2nd edn. Plymouth, UK

Cochrane SJ (2003) Snowflakes and feather-dusters-some challenges for soft-bottom fanworm systematics. Hydrobiologia 496:49-62

Colwell RK (2009) EstimateS: Statistical estimation of species richness and shared species from samples. Version 8.2. User's Guide and application published at http://purl.oclc.org/estimates

Danovaro R, Dinet A, Duineveld G, Tselepsides A (1999) Benthic response to particulate fluxes in different trophic environments: a comparison between the Gulf of Lions-Cataln Sea (W-Mediterranean) and the Cretan Sea (E-Mediterranean). Prog Oceanogr 44:287-312

Eilertsen HC, Taasen JP, Węsławski JM (1989) Phytoplankton studies in the fjords of West Spitsbergen. Physical environment, production in spring and summer. J Plankton Res 11:1245-1260

Fauchald K, Jumars PA (1979) The diet of worms: a study of polychaete feeding guilds. Oceanogr Mar Biol Annu Rev 17:193-284

Feder HM, Iken K, Blanchard AL, Jewett SC, Schonberg S (2011) Food web structure in the southeastern Chukchi Sea: an assessment using $\delta^{13} \mathrm{C}$ and $\delta^{15} \mathrm{~N}$ analyses. Polar Biol 34:521-532

Giangrande A, Licciano M, Musco L (2005) Polychaetes as environmental indicators revisited. Mar Poll Bull 50:1153-1162

Görlich K, Węsławski JM, Zajaczkowski M (1987) Suspension settling effect on macrobenthos biomass distribution in the Hornsund fjord, Spitsbergen. Polar Res 5:175-192

Grebmeier JM (2012) Shifting patterns of life in the Pacific Arctic and sub-arctic seas. Ann Rev Mar Sci 4:63-78

Grebmeier JM, Cooper LW, Feder HM, Sirenko BI (2006) Ecosystem dynamics of the Pacific-influenced Northern Bering and Chukchi Seas in the Amerasian Arctic. Prog Oceanogr 71:331-361

Gromisz S (1992) Occurence and species composition of polychaeta (Annelida) in Hornsund fiord (south Spitsbergen). In: Opaliński KW, Klekowski RZ (eds) Landscape, life world and man in High Arctic. Institute of Ecology PAS, Warszawa, pp 199-206

Grzelak K, Kotwicki L (2012) Meiofaunal distribution in Hornsund fjord, Spitsbergen. Polar Biol 35:269-280

Hartmann-Schröder G (1996) Annelida, Borstenwürmer, Polychaeta [Annelida, bristleworms, Polychaeta]. The fauna of Germany and adjacent seas with their characteristics and ecology, 2nd revised edition, pp 1-648

Holthe T (1986) Polychaeta Terebellomorpha. In: Marine invertebrates of Scandinavia. Norvegian University Press, Oslo, vol 7, pp 1-194

Holte B, Oug E (1996) Soft-bottom macrofauna and responses to organic enrichment in the subarctic waters of Tromso, northern Norway. J Sea Res 36:227-237

Holte B, Dahle S, Gulliksen B, Naes K (1996) Some macrofaunal effects of local pollution and glacier-induced sedimentation, with indicative chemical analyses, in the sediments of two Arctic fjords. Polar Biol 16:549-557

Hop H, Pearson T, Hegseth EN, Kovacs K, Wiencke C, Kwasniewski S, Eiane K, Mehlum F, Gulliksen B, WlodarskaKowalczuk M, Lydersen C, Weslawski JM, Cochrane S, Gabrielsen GW, Leakey R, Lønne OJ, Zajaczkowski M, Falk-Petersen S, Kendall M, Wängber SA, Bischof K, Voronkov A, Kovaltchouk NA, Wiktor 
J, Poltermann M, di Prisco G, Papucci C, Gerland S (2002) The marine ecosystem of Kongsfjorden, Svalbard. Polar Res 21:167-208

Hutchings P (1998) Biodiversity and functioning of polychaetes in benthic sediments. Biodivers Cons 7:1133-1145

Jażdżewski K, de Broyer C, Węsławski JM (1995) A comparison of the amphipod faunal diversity in two polar fjords: Admiralty Bay, King George Island (Antarctic) and Hornsund, Spitsbergen (Arctic). Pol Arch Hydrobiol 42:367-384

Jirkov IA (2001) Polychaeta of the Arctic Ocean. Yanus-K Press, Moscow

Kędra M, Murina GV (2007) The sipunculan fauna of Svalbard. Polar Res 26:37-47

Kędra M, Włodarska-Kowalczuk M (2008) Distribution and diversity of sipunculan fauna in high Arctic fjords (west Svalbard). Polar Biol 31:1181-1190

Kędra M, Włodarska-Kowalczuk M, Węsławski JM (2010a) Decadal change in macrobenthic soft-bottom community structure in a high Arctic fjord (Kongsfjorden, Svalbard). Polar Biol 33:1-11

Kędra M, Gromisz S, Jaskuła R, Legeżyńska J, Maciejewska B, Malec E, Opanowski A, Ostrowska K, Włodarska-Kowalczuk M, Węsławski JM (2010b) Soft bottom macrofauna of an All Taxa biodiversity site: Hornsund $\left(77^{\circ} \mathrm{N}\right.$, Svalbard). Pol Polar Res 31:309-326

Kendall MA, Aschan M (1993) Latitudinal gradients in the structure of macrobenthic communities: a comparison of Arctic, temperate and tropical sites. J Exp Mar Biol Ecol 172:157-169

Kendall MA, Widdicombe S, Węsławski JM (2003) A multi-scale study of the biodiversity of the benthic infauna of the highlatitude Kongsfjord, Svalbard. Polar Biol 26:383-388

Knox G (1977) The role of polychaetes in benthic soft-bottom communities. In: Reish DJ, Fauchald K (eds) Essays on polychaetous annelids in memory of Dr. Olga Hartman. Allan Hancock Foundation, Los Angeles, pp 547-604

Kruse I (2003) Population ecology and genetics of the polychaete Scoloplos armiger (Orbiniidae). Berichte zur Polar und Meeresforschung 438:1-95

Legeżyńska J, Węsławski JM, Presler P (2000) Benthic scavengers collected by baited traps in the high Arctic. Polar Biol 23:539-544

Lippert H, Iken K, Rachor E, Wiencke C (2001) Macrofauna associated with macroalgae in the Kongsfjorden (Spitsbergen). Polar Biol 24:512-522

Magurran AE (2004) Measuring biological diversity. Blackwell, Carlton

Olsgard F, Hasle JR (1993) Impact of waste from titanium mining on benthic fauna. J Exp Mar Biol Ecol 172:185-213

Olsgard F, Somerfield PJ (2000) Surrogates in marine benthic investigations - which taxonomic unit to target? J Aquat Ecosyst Stress Recovery 7:25-42

Olsgard F, Brattegard T, Holthe T (2003) Polychaetes as surrogates for marine biodiversity: lower taxonomic resolution and indicator groups. Biodivers Conserv 12:1033-1049

Pabis K, Siciński J (2010) Distribution and diversity of polychaetes collected by trawling in Admiralty Bay: an Antarctic glacial fiord. Polar Biol 33:141-151

Pearson TH, Rosenberg R (1978) Macrobenthic succession in relation to organic enrichment and pollution of the marine environment. Oceanogr Mar Biol Annu Rev 16:229-311

Piechura J, Walczowski W (2009) Warming of the West Spitsbergen Current and sea ice north of Svalbard. Oceanologia 51:149-164

Piwosz K, Walkusz W, Hapter R, Wieczorek P, Hop H, Wiktor J (2009) Comparison of productivity and phytoplankton in a warm (Kongsfjorden) and a cold (Hornsund) Spitsbergen fjord in midsummer 2002. Polar Biol 32:549-559

Pocklington P, Wells PG (1992) Polychaetes key taxa for marine environmental quality monitoring. Mar Pollut Bull 24:593-598
Polyakov IV, Timokhov LA, Alexeev VA, Bacon S, Dimitrenko IA, Fortier L, Frolov IE, Gascard JC, Hansen E, Ivanov VV, Laxon S, Mauritzen C, Perovich D, Shimada K, Simmons HL, Sokolov VT, Steele M, Toole J (2010) Arctic Ocean warming contributes to reduced polar cap. J Phys Oceanogr 40:L2743-L2756

Post E, Forchhammer MC, Bret-Harte MS, Callaghan TV, Christensen TR, Elberling B, Fox AD, Gilg O, Hik DS, Hoye TT, Ims RA, Jeppesen E, Klein DR, Madsen J, McGuire AD, Rysgaard S, Schindler DE, Stirling I, Tamstrof MP, Tyler NJC, van der Wal R, Welker J, Wookey PA, Schmidt NM, Aastrup P (2009) Ecological dynamics across the arctic associated with recent climate change. Science 325:1355-1358

Renaud PE, Wlodarska-Kowalczuk M, Trannum H, Holte B, Węsawski JM, Cochrane S, Dahle S, Gulliksen B (2007) Multidecadal stability of benthic community structure in a high-Arctic glacial fjord (van Mijenfjord, Spitsbergen). Polar Biol 30:295-305

Ronowicz M (2005) Species diversity of Arctic gravel beach: case study for species poor habitats. Pol Polar Res 26:287-297

Ronowicz M, Włodarska-Kowalczuk M, Kuklinski P (2008) Factors influencing hydroids (Cnidaria: Hydrozoa) biodiversity and distribution in Arctic kelp forest. J Mar Biol Assoc UK 88:1567-1575

Ronowicz M, Włodarska-Kowalczuk M, Kuklinski P (2011) Patterns of hydroid (Cnidaria, Hydrozoa) species richness and distribution in an Arctic glaciated fjord. Polar Biol 34:1437-1445

Rouse GW, Pleijel F (2001) Polychaetes. Oxford University Press, New York

Siciński J (2004) Polychaetes of Antarctic sublittoral in the proglacial zone (King George Island, South Shetland Islands). Pol Polar Res 25:67-96

Siciński J, Pabis K, Jażdżewski K, Konopacka A, BłażewiczPaszkowycz M (2012) Macrozoobenthos of two Antarctic glacial coves: a comparison with non-disturbed bottom areas. Polar Biol 35:355-367

Snelgrove PVR, Blackburn TM, Hutchings PA, Alongi DM, Grassle JF, Hummel H, King G, Koike I, Lambshead PJD, Ramsing NB, Solis-Weiss V (1997) The importance of marine sediment biodiversity in ecosystem processes. Ambio 26:578-583

Steele M, Ermold W, Zhang J (2008) Arctic Ocean surface warming trends over the past 100 years. Geophys Res Lett 35:L02614

Svendsen H, Beszczynska-Möller A, Hagen JO, Lefauconnier B, Tverberg V, Gerland S, Ørbæk JB, Bischof K, Papucci C, Zajaczkowski M, Azzolini R, Bruland O, Wiencke C, Winther JG, Dallmann W (2002) The physical environment of KongsfjordenKrossfjorden, an arctic fjord system in Svalbard. Polar Res 21:133-166

Swerpel S (1985) The Hornsund fiord: water masses. Pol Polar Res 4:475-496

Syvitski JPM, Andrews JT (1994) Climate change: numerical modelling of sedimentation and coastal processes, eastern Canadian Arctic. Arct Alp Res 26:199-212

Szczuciński W, Schettler G, Zajączkowski M (2006) Sediment accumulation rates, geochemistry and provenance in complex High Arctic fjord, Hornsund, Svalbard. In: Fourth ESF SEDIFLUX science meeting and first workshop of I.A.G./A.I.G. SEDIBUD: Source-to-SInk-Fluxes and sediment budgets in cold environments. NGF abstracts and proceedings of the geological society of Norway, vol 4, p 65

Turner J, Overland J (2009) Contrasting climate change in the two polar regions. Polar Res 28:146-164

Urbański J, Neugebauer E, Spacjer R, Falkowska L (1980) Physico chemical characteristics of the waters of Hornsund fjord on South West Spitsbergen. Pol Polar Res 1:43-52

Walczowski W, Piechura J (2006) New evidence of warming propagating toward the Arctic Ocean. Geophys Res Lett 33:L12601 
Walczowski W, Piechura J (2007) Pathways of the Greenland Sea warming. Geophys Res Lett 34:L10608

Walsh JE (2009) A comparison of Arctic and Antarctic climate change, present and future. Antarct Sci 21:179-188

Warwick RM, Emblow CS, Féral J-P, Hummel H, van Avesaath P, Heip C (2003) European marine biodiversity research sites. Report of the European Concerted Action: BIOMARE NIOOCEME, Yerseke, The Netherlands, p 136

Węsławski JM, Jankowski A, Kwaśniewski S, Swerpel S, Ryg M (1991) Summer hydrology and zooplankton in two Svalbard fiords. Pol Polar Res 12:445-460

Węsławski JM, Koszteyn J, Zajączkowski M, Wiktor J, Kwaśniewski S (1995) Fresh water in Svalbard fjord ecosystems. In: Hopkins CC, Erikstad KE, Leinaas HP (eds) Ecology of fjord and coastal watered. Elsevier, Amsterdam, pp 229-241

Węsławski JM, Kendall MA, Włodarska-Kowalczuk M, Iken K, Kędra M, Legeżyńska J, Sejr MK (2011) Climate change effects on Arctic fjord and coastal macrobenthic diversity-observations and predictions. Mar Biodivers 41:71-85

Włodarska-Kowalczuk M, Pearson TH (2004) Soft-bottom macrobenthic faunal associations and factors affecting species distribution in an Arctic glacial fjord (Kongsfjord, Spitsbergen). Polar Biol 27:155-167

Włodarska-Kowalczuk M, Kędra M (2007) Surrogacy in natural patterns of benthic distribution and diversity: lower taxonomic resolution versus indicator groups. Mar Ecol Prog Ser 352:53-63

Włodarska-Kowalczuk M, Węsławski JM (2008) Mesoscale spatial structures of soft-bottom macrozoobenthos: effects of physical control and impoverishment. Mar Ecol Prog Ser 356:215-224

Włodarska-Kowalczuk M, Węsławski JM, Kotwicki L (1998) Spitsbergen glacial bays macrobenthos: a comparative study. Polar Biol 20:66-73

Włodarska-Kowalczuk M, Pearson TH, Kendall MA (2005) Benthic response to chronic natural physical disturbance by glacial sedimentation in an Arctic fjord. Mar Ecol Prog Ser 303:31-41

Włodarska-Kowalczuk M, Kukliński P, Ronowicz M, Legeżyńska J, Gromisz S (2009) Assessing species richness of macrofauna associated with macroalgae in Arctic kelp forest (Hornsund, Svalbard). Polar Biol 32:897-905 